\title{
Solar Cells: In Research and Applications-A Review
}

\author{
Shruti Sharma1, Kamlesh Kumar Jain ${ }^{1}$, Ashutosh Sharma ${ }^{2 *}$ \\ ${ }^{1}$ CMD College, Bilaspur, India \\ ${ }^{2}$ Materials Science and Engineering, University of Seoul, Seoul, South Korea \\ Email: "stannum.ashu@gmail.com
}

Received 28 October 2015; accepted 21 December 2015; published 24 December 2015

Copyright (C) 2015 by authors and Scientific Research Publishing Inc.

This work is licensed under the Creative Commons Attribution International License (CC BY). http://creativecommons.org/licenses/by/4.0/

\section{c) (i) Open Access}

\begin{abstract}
The light from the Sun is a non-vanishing renewable source of energy which is free from environmental pollution and noise. It can easily compensate the energy drawn from the non-renewable sources of energy such as fossil fuels and petroleum deposits inside the earth. The fabrication of solar cells has passed through a large number of improvement steps from one generation to another. Silicon based solar cells were the first generation solar cells grown on Si wafers, mainly single crystals. Further development to thin films, dye sensitized solar cells and organic solar cells enhanced the cell efficiency. The development is basically hindered by the cost and efficiency. In order to choose the right solar cell for a specific geographic location, we are required to understand fundamental mechanisms and functions of several solar technologies that are widely studied. In this article, we have reviewed a progressive development in the solar cell research from one generation to other, and discussed about their future trends and aspects. The article also tries to emphasize the various practices and methods to promote the benefits of solar energy.
\end{abstract}

\section{Keywords}

Solar Energy, Fossils, Power, Pollution, Renewable

\section{Introduction}

Everyday sun sends out tremendous amount of energy in the form of heat and radiations called solar energy. Solar energy is a limitless source of energy which is available at no cost [1] [2]. The major benefit of solar energy over other conventional power generators is that the sunlight can be directly harvested into solar energy with the use of small and tiny photovoltaic (PV) solar cells [3] [4]. The Sun is assumed as a big spherical ga-

*Corresponding author. 
seous cloud made up of hydrogen and helium atoms. This big spherical gaseous cloud is mainly composed of several hydrogen nu lei combining to form helium energy with the emission of energy from the fusion of the hydrogen nuclei in inner core of the Sun via nuclear fusion (Figure 1) [5].

$$
\begin{aligned}
& { }_{1}^{2} \mathrm{H}+{ }_{1}^{2} \mathrm{H} \rightarrow{ }_{2}^{3} \mathrm{He}+{ }_{0}^{1} n+3.27 \mathrm{MeV} \\
& { }_{1}^{2} \mathrm{H}+{ }_{1}^{3} \mathrm{H} \rightarrow{ }_{2}^{4} \mathrm{He}+{ }_{0}^{1} n+17.59 \mathrm{MeV}
\end{aligned}
$$

During this process of fusion, four hydrogen atoms combine to form one helium atom with a loss of mass which is radiated as thermal energy [1] [4]-[5]. This radiant energy produced by fusion reactions is free from any pollutant, gases, or other reaction by-product. This is why it is the major driving force of all the clean energy technology, in view of the climatic disturbance caused by the emission of carbon from the fossil fuels deposits. One of the biggest advantages of solar energy is that it is free reachable to common people and available in abundant supply compared to that of the price of various fossil fuels and oils in the past decade [1]-[7]. Moreover, solar energy requires considerably lower manpower expenses over conventional energy production technology.

Though the solar energy is freely available everywhere, there is still an initial expenditure on the equipments for harvesting this radiant energy by developing solar cells, panels and modules [8]. These small and tiny solar cells produce no noise during their operation. On the other hand, the big power pumping devices produce unbearable sound pollution, and therefore they are very disturbing to the society [6]-[8]. Nowadays, due to the decreasing amount of renewable energy resources, the per watt cost of solar energy device has become more important in the last decade, and is definitely set to become economical in the coming years and grow as better technology in terms of both cost and applications [9] [10].

In spite of numerous advantages, this energy has few limitations too. Firstly, solar energy doesn't radiate at night. Secondly, the solar energy is almost not constant all the time. There must be plenty of sunlight available to generate electrical energy from a solar PV device [7] [10] [11]. Moreover, apart from daily fluctuations in the intensity of radiant energy, the solar energy is hindered to reach the earth during bad climatic conditions. For example, the amount of sunlight reaching the earth's surface depends on location, time as well as weather as it falls during winter season as compared to the summer, and the Sun's radiation is less intense [10] [11]. To overcome these demerits of this technology, solar energy must be stored elsewhere at night and the highly efficient solar cells and modules needs to be developed.

There have been an enormous amount of research activities to harvest the Sun's energy effectively by developing solar cells/panels with high conversion efficiencies. The photovoltaic conversion efficiency is referred to the efficiency of solar PV modules, and is defined as the fraction of Sun's energy that can be converted into electricity. Solar panels are a huge collection of tiny solar cells arranged in a definite geometrical shape to produce a given amount of power supply. The storage of solar power is still has not been achieved successfully. Currently the radiation efficiency of solar panel is up to $22 \%$ [11]. There are many solar photovoltaic batteries available which are usually more expensive and bulky. These are more suitable for small scale or household solar needs compared to large solar plants [12] [13].

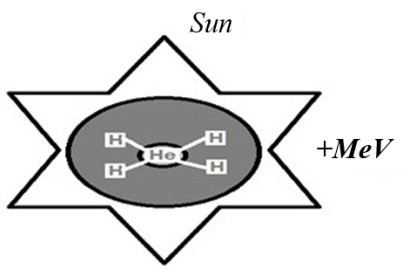

${ }_{1}^{2} \mathrm{H}+{ }_{1}^{2} \mathrm{H} \rightarrow{ }_{2}^{3} \mathrm{He}+{ }_{0}^{1} \mathrm{n}+3.27 \mathrm{MeV}$

${ }_{1}^{2} \mathrm{H}+{ }_{1}^{3} \mathrm{H} \rightarrow{ }_{2}^{4} \mathrm{He}+{ }_{0}^{1} n+17.59 \mathrm{MeV}$

Figure 1. Nuclear fusion reaction: source of solar energy [5]. 
The working mechanism of solar cells is based on the three factors: (1) Adsorption of light in order to generate the charge careers, holes (p-type) and electrons (n-type) (2) Separation of charge careers, and (2) the collection of charge careers at the respective electrodes establishing the potential difference across the p-n junction. The generation of voltage difference noticed at the p-n junction of the cell in response to visible radiation is utilized to do the work.

In the past, various kinds of semiconductor materials and technologies are devised to design solar cells with low cost as well as high conversion efficiency. Traditional solar panels made from silicon crystalline wafer modules are heavier which makes the transportation difficult. These are generally the large sized solar panels covered with glass sheets. A heavier and bulky solar panel requires a lot of space and sometime big roofs to fit these bulky and large solar panels in case of high power applications [11]-[13]. Therefore, in this article keeping in mind the efficient use of solar energy by solar cells research and development, we will study the different types of solar cells.

\section{Solar Cells}

The photovoltaic (PV) effect was first observed by Alexandre-Edmond Becquerel in 1839 [14]. Subsequently, in 1946 the first modern solar cell made of silicon was invented by Russel Ohl [14] [15]. Earlier photovoltaic solar cells are thin silicon wafers that transform sunlight energy into electrical power. The modern photovoltaic technology is based on the principle of electron hole creation in each cell composed of two different layers (p-type and n-type materials) of a semiconductor material, as shown in Figure 2. In this arrangement of the structure, when a photon of sufficient energy impinges on the p-type and n-type junction, an electron is ejected by gaining energy from the striking photon and moves from one layer to another. This creates an electron and a hole in the process and by this process electrical power is generated [16]. The various types of materials applied for photovoltaic solar cells includes mainly in the form of silicon (single crystal, multi-crystalline, amorphous silicon) [3]-[6], cadmium-telluride [3] [4], copper-indium-gallium-selenide [3] [4] [8], and copper-indium-gallium-sulfide [10] [16]. On the basis of these materials, the photovoltaic solar cells are categorized into various classes as discussed in the following sections (also shown in Figure 3).

\subsection{First Generation Solar Cell-Wafer Based}

As it is already mentioned, the first generation solar cells are produced on silicon wafers. It is the oldest and the most popular technology due to high power efficiencies. The silicon wafer based technology is further categorized into two subgroups named as [2]-[4] [10] [16].

- Single/ Mono-crystalline silicon solar cell.

- Poly/Multi-crystalline silicon solar cell.

\subsubsection{Single/Mono-Crystalline Silicon Solar Cell}

Mono crystalline solar cell, as the name indicates, is manufactured from single crystals of silicon by a process called Czochralski process [16]-[18]. During the manufacturing process, Si crystals are sliced from the big sized ingots. These large single crystal productions require precise processing as the process of "recrystallizing" the cell is more expensive and multi process. The efficiency of mono-crystalline single-crystalline silicon solar cells lies between $17 \%$ - $18 \%$ [8].

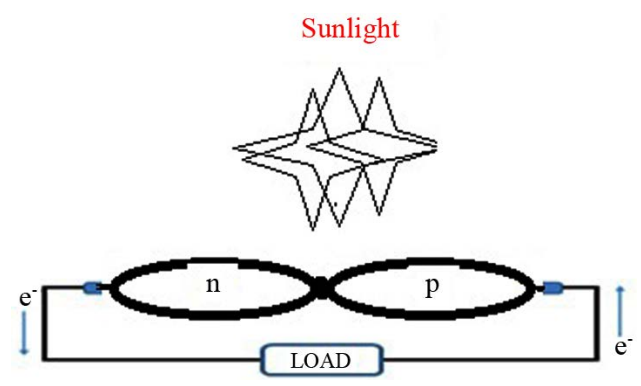

Figure 2. The semiconductor $\mathrm{p}-\mathrm{n}$ junction solar cell under load. 


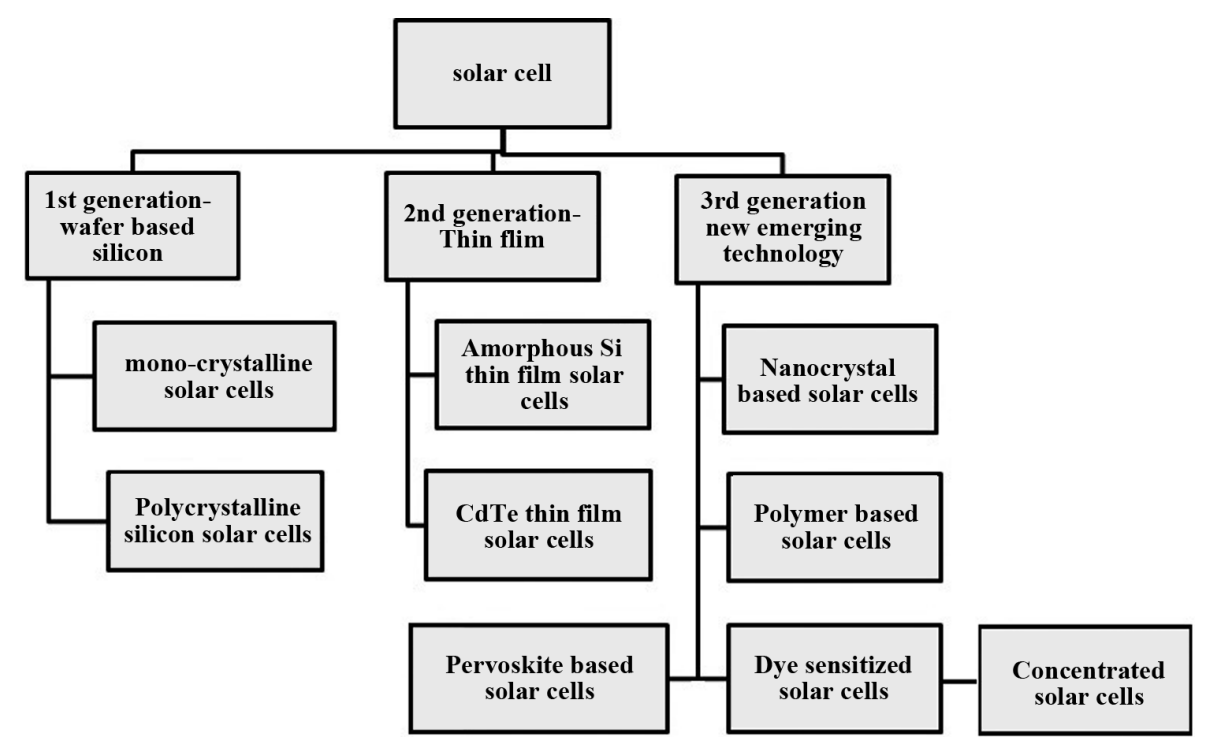

Figure 3. Various types of solar cell technologies and current trends of development [2] [16].

\subsubsection{Polycrystalline Silicon Solar Cell (Poly-Si or Mc-Si)}

Polycrystalline PV modules are generally composed of a number of different crystals, coupled to one another in a single cell. The processing of polycrystalline Si solar cells is more economical, which are produced by cooling a graphite mold filled containing molten silicon. Polycrystalline Si solar cells are currently the most popular solar cells. They are believed to occupy most up to $48 \%$ of the solar cell production worldwide during 2008 [19]. During solidification of the molten silicon, various crystal structures are formed. Though they are slightly cheaper to fabricate compared to monocrystalline silicon solar panels, yet are less efficient $~ 12 \%-14 \%$ [20].

\subsection{Second Generation Solar Cells-Thin Film Solar Cells}

Most of the thin film solar cells and a-Si are second generation solar cells, and are more economical as compared to the first generation silicon wafer solar cells. Silicon-wafer cells have light absorbing layers up to 350 $\mu \mathrm{m}$ thick, while thin-film solar cells have a very thin light absorbing layers, generally of the order of $1 \mu \mathrm{m}$ thickness [21]. Thin film solar cells are classified as;

- a-Si.

- CdTe.

- CIGS (copper indium gallium di-selenide).

\subsubsection{Amorphous Silicon Thin Film (a-Si) Solar Cell}

Amorphous Si (a-Si) PV modules are the primitive solar cells that are first to be manufactured industrially. Amorphous (a-Si) solar cells can be manufactured at a low processing temperature, thereby permitting the use of various low cost, polymer and other flexible substrates. These substrates require a smaller amount of energy for processing [22]. Therefore, a-Si amorphous solar cell is comparatively cheaper and widely available. The "amorphous" word with respect to solar cell means that the comprising silicon material of the cell lacks a definite arrangement of atoms in the lattice, non-crystalline structure, or not highly structured. These are fabricated by coating the doped silicon material to the backside of the substrate/glass plate. These solar cells generally are dark brown in color on the reflecting side while silverish on the conducting side [23].

The mainissue of a-Si solar cell is the poor and almost unstable efficiency. The cell efficiency automatically falls at PV module level. Currently, the efficiencies of commercial PV modules vary in the range of $4 \%-8 \%$. They can be easily operated at elevated temperatures, and are suitable for the changing climatic conditions where sun shines for few hours [24].

\subsubsection{Cadmium Telluride (CdTe) Thin Film Solar Cell}

Among thin-film solar cells, cadmium telluride (CdTe) is one of the leading candidate for the development of 
cheaper, economically viable photovoltaic (PV) devices, and it is also the first PV technology at a low cost [8] [25] [26]. CdTe has a band gap of $\sim 1.5 \mathrm{eV}$ as well as high optical absorption coefficient and chemical stability. These properties make CdTe most attractive material for designing of thin-film solar cells.

CdTe is an excellent direct band gap crystalline compound semiconductor which makes the absorption of light easier and improves the efficiency. It is generally constructed by sandwiching between cadmium sulfide layers to form a p-n junction diode. The manufacturing process involves three steps: Firstly, the CdTe based solar cells are synthesized from polycrystalline materials and glass is chosen a substrate. Second process involves deposition, i.e., the multiple layers of CdTe solar cells are coatedon to substrate using different economical methods. It is already mentioned that CdTe has a direct optimum band gap $(\sim 1.45 \mathrm{eV})$ with high absorption coefficient over $5 \times 10^{15} / \mathrm{cm}$ [27]. Therefore, its efficiency usually operates in the range $9 \%-11 \%$ [8] [28]. CdTe solar cells can be made on polymer substrates and flexible. However, there are various environmental issues with cadmium component of solar cell. Cadmium is regarded as a heavy metal and potential toxic agent that can accumulate in human bodies, animals and plants. The disposal of the toxic Cd based materials as well as their recycling can be highly expensive and damaging too to our environment and society [10] [24]. Therefore, a limited supply of cadmium and environmental hazard associated with its use are the main issues with this CdTe technology [26]-[29].

\subsubsection{Copper Indium Gallium Di-Selenide (CIGS) Solar Cells}

CIGS is a quaternary compound semiconductor comprising of the four elements, namely: Copper, Indium, Gallium and Selenium [10] [30]. CIGS are also direct band gap type semiconductors. Compared to the CdTe thin film solar cell, CIGS hold a higher efficiency $10 \%-12 \%$. Due to their significantly high efficiency and economy, CIGS based solar cell technology forms one of the most likely thin film technologies. The processing of CIGS are done by the following techniques: sputtering, evaporation, electrochemical coating technique, printing and electron beam deposition [16] [31]. In addition, the sputtering can be a two or multi-step process involving with deposition and subsequent interaction with selenium later, or can be a one-step reactive process. However, evaporation is similar to the sputtering in the sense that it can be used in a single step, two-step or multiple processing steps. The substrates for CIGS material can be chosen from glass plate, polymers substrates, steel, aluminum etc. The advantages of CIGS thin film solar cells include its prolonged life without a considerable degradation. These properties of CIGS indicate an easy solution to enhance the efficiency [8] [22] [28]. Table 1 shows a comparison of popular wafer based solar cell and thin film solar cell [16] [17].

\subsection{Third Generation Solar Cells}

Third generation cells are the new promising technologies but are not commercially investigated in detail. Most of the developed 3rd generation solar cell types are [2]:

1) Nano crystal based solar cells.

2) Polymer based solar cells.

3) Dye sensitized solar cells.

4) Concentrated solar cells.

\subsubsection{Nano Crystal Based Solar Cells}

Nanocrystal based solar cells are generally also known as Quantum dots (QD) solar cells. These solar cells are composed of a semiconductor, generally from transition metal groups which are in the size of nanocrystal range made of semiconducting materials. QD is just a name of the crystal size ranging typically within a few nanometers in size, for example, materials like porous $\mathrm{Si}$ or porous $\mathrm{TiO}_{2}$, which are frequently used in QD [32]. The structure of the QD solar cells are shown in Figure 4 [10]. With the advance of nanotechnology, these nanocrystals of semiconducting material are targeted to replace the semiconducting material in bulk state such as $\mathrm{Si}$, CdTe or CIGS. This idea of the QD based solar cell with a theoretical formulation were employed for the design of a p-i-n solar cell over the self-organized in As/GaAs system [32]. Generally, the nanocrystals are mixed into a bath and coated onto the Si substrate. These crystals rotate very fast and flow away due to the centrifugal force. In conventional compound semiconductor solar cells, generally a photon will excite an electron there by creating one electron-hole pair [33]. However, when a photon strikes a QD made of the similar semiconductor material, numerous electron-hole pairs can be formed, usually 2 or 3, also 7 has been observed in few cases [2] [29]. 


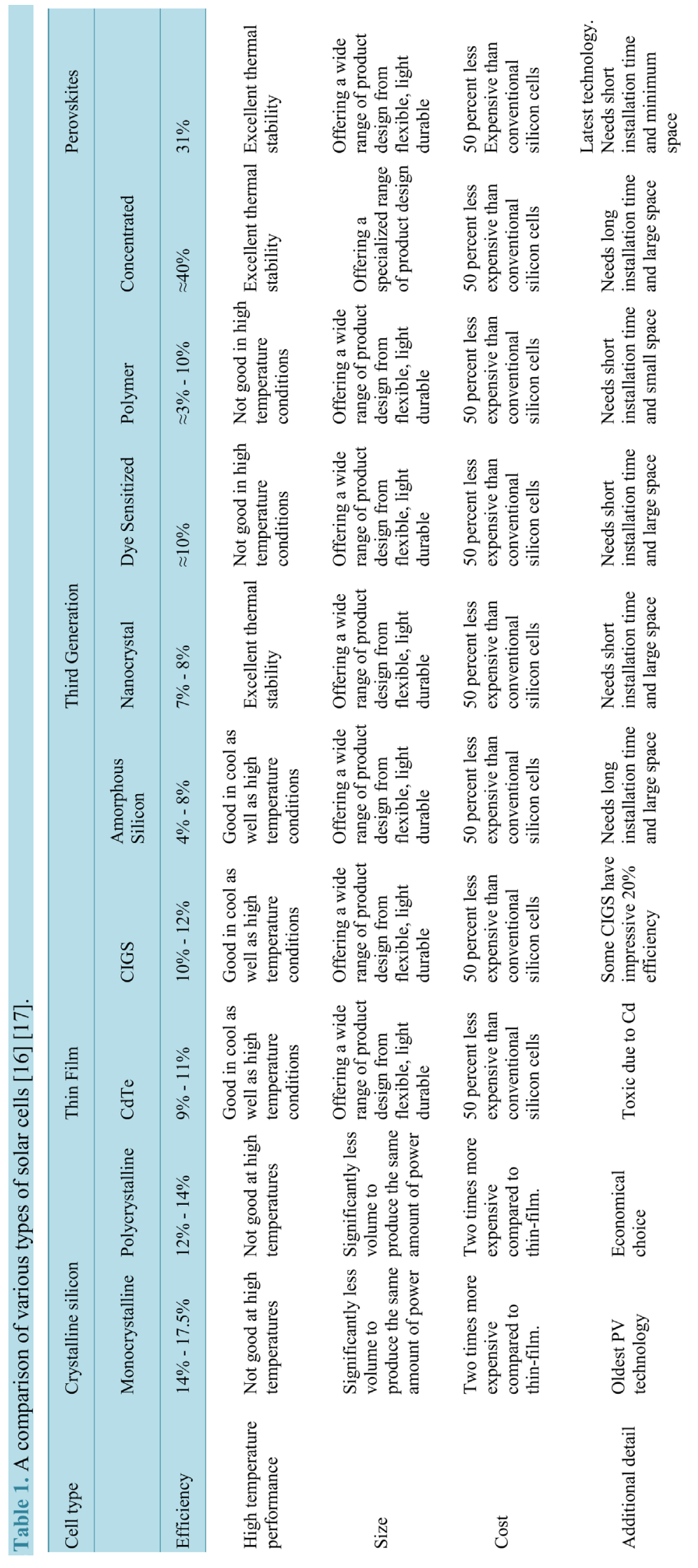




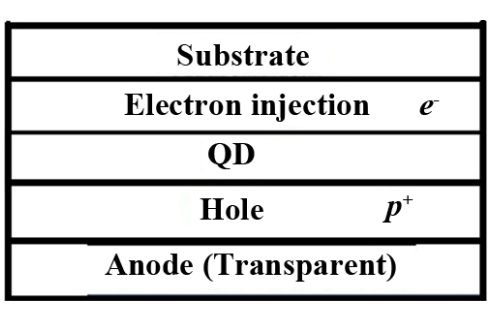

Figure 4. A schematic of Quantum dot (QD) layer [32].

\subsubsection{Polymer Solar Cells}

Polymer solar cells (PSC) are generally flexible solar cells due to the polymer substrate. The first PSC were invented by the research group of Tang et al. at Kodak Research Lab. [2]. A PSC is composed of a serially connected thin functional layers coated on a polymer foil or ribbon. It works usually as a combination of donor (polymer) and a acceptor (fullerene). There are various types of materials for the absorption of sunlight, including organic material like a conjugate/conducting polyme [2] [34]. In 2000, Heeger, MacDiarmid, and Shirakawa fetched the Nobel Prize in Chemistry for the discovering a new category of polymer materials known as conducting polymers [35] [36]. The PSC and other organic solar cells operate on same principle known as the photovoltaic effect, i.e., where the transformation of the energy occurs in the form of electromagnetic radiations into electrical current [37]. Yu et al. mixedpoly [2-methoxy-5-(2'-ethylhexyloxy)-p-phenylene vinylene] (PPV), C60 and its other derivatives to develop the first polymer solar cell and obtained a high power conversion efficiency [38]. This process triggered the development of a new age in the polymer materials for capturing the solar power. After significantly optimizing the parameters, researchers achieved efficiency over 3.0\% for PPV type PSCs [38]-[40]. These unique properties of PSCs opened a new gateway for new applications in the formation of stretchable solar devices including textiles and fabrics [39]. A modern recycling concept known as polarizing organic photovoltaics (ZOPVs) was also developed for increasing the function of liquid crystal displays utilizing the same polarizer, a photovoltaic device and proper light conditions/solar panel [39]-[41].

\subsubsection{Dye Sensitized Solar Cells (DSSC)}

Recent research has been focused on improving solar efficiency by molecular manipulation, use of nanotechnology for harvesting light energy [42]-[45]. The first DSSC solar cell was introduced by Michel Gratzel in Swiss federal institute of technology [10] [16]. DSSCs based solar cells generally employ dye molecules between the different electrodes. The DSSC device consists of four components: semiconductor electrode (n-type $\mathrm{TiO}_{2}$ and p-type NiO), a dye sensitizer, redox mediator, and a counter electrode (carbon or Pt) [46]. The DSSCs attractive due to the simple conventional processing methods like printing techniques, are highly flexible, transparent and low cost as well [10]. The novelty in the DSSC solar cells arise due to the photosensitization of nano grained $\mathrm{TiO}_{2}$ coatings coupled with the visible optically active dyes, thus increasing the efficiencies greater than $10 \%$ [42]-[44] [46] [47]. However, there are certain challenges like degradation of dye molecules and hence stability issues [10]. This is due to poor optical absorption of sensitizers which results in poor conversion efficiency. The dye molecules generally degrade after exposure to ultraviolet and infrared radiations leading to a decrease in the lifetime and stability of the cells. Moreover, coating with a barrier layer may also increase the manufacturing more expensive and lower the efficiency [8].

\subsubsection{Concentrated Solar Cells}

Concentrating photovoltaic (CPV) has been established since the 1970s [45] [48] [49]. It is the newest technology in the solar cell research and development. The main principle of concentrated cells is to collect a large amount of solar energy onto a tiny region over the PV solar cell, as shown in Figure 5. The principle of this technology is based on optics, by using large mirrors and lens arrangement to focus sunlight rays onto a small region on the solar cell [8]. The converging of the sunlight radiations thus produces a large amount of heat energy. This heat energy is further driven by a heat engine controlled by a power generator with integrated. CPVs have shown their promising nature in solar world [49] [50]. It ca n be classified into low, medium, and high concentrated solar cells depending on the power of the lens systems [49]. Concentrating photovoltaic technology have the following merits, such as solar cell efficiencies $>40 \%$, absence of any moving parts, no thermal mass, speedy response time and can be scalable to a range of sizes. 


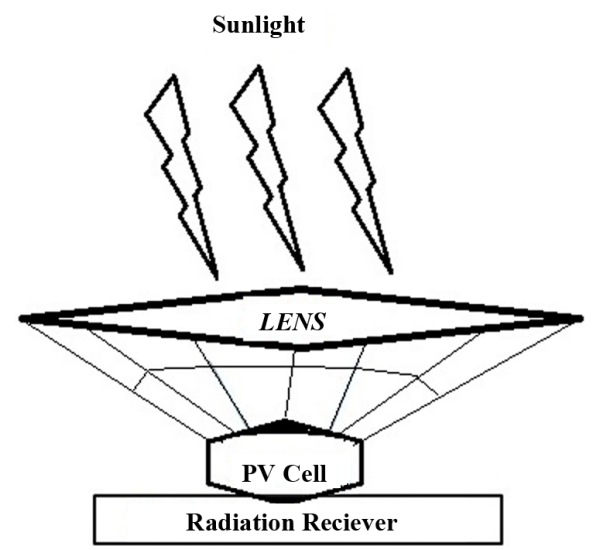

Figure 5. Schematic of concentrated solar cell [48] [49].

\subsection{Perovskite Based Solar Cell}

Perovskites are a class of compounds defined by the formula $\mathrm{ABX}_{3}$ where $\mathrm{X}$ represents a halogen such as $\mathrm{I}^{-}, \mathrm{Br}^{-}$, $\mathrm{Cl}^{-}$. and A and B are cations of different size. Perovskite solar cells are recent discovery among the solar cell research community and possess several advantages over conventional silicon and thin film based solar cells. Conventional Si based solar cells need expensive, multiple processing steps and require high temperatures $\left(>1000^{\circ} \mathrm{C}\right)$ and vacuums facilities [51] [52]. The perovskites based solar cells can have efficiency up to 31\% [53]. It can be predicted that these perovskites may also play an important role in next-generation electric automobiles batteries, according to an interesting investigation recently performed by Volkswagen [52] [53]. However, current issues with perovskite solar cells are their stability and durability. The material degrades over time, and hence a drop in overall efficiency. Therefore more research is needed to bring these cells into the market place.

\section{Advances in Energy Storage}

Since the sunlight is not always available, all these businesses of PV solar cells may not work at night and a lot of electricity will go unused [54]. Therefore energy storage is an important factor in solar cell market. A comparison and summary of various types of solar cells is summarized in Table 1.

Several energy storage devices are available in the market but those are highly expensive and a short life span. Recently, in 2014, Harvard University researchers developed a new type of battery based on organic molecules called Quinone. It is found in plants and is economical in a sense that it can store sunlight energy for a couple of days [55].

The world's first solar cell energy storage is introduced by Wu and his co-workers at Ohio State University. This device not only can store energy but can also reduce the costs of renewable energy by $25 \%$, relying on a new aqueous, rechargeable lithium-oxygen battery used in sunlight [56].

\section{Conclusion}

Solar power generation has been developed as one of the most demanding renewable sources of electricity. It has several advantages compared to other forms of energy like fossils fuels and petroleum deposits. It is an alternative which is promising and consistent to meet the high energy demand. Though the methods of utilizing solar energy are simple, yet need an efficient and durable solar material. Technology based on nano-crystal QD of semiconductors based solar cell can theoretically convert more than sixty percent of the whole solar spectrum into electric power. The polymer base solar cells are also a viable option. However, their degradation over time is a serious concern. There are various challenges for this industry, including lowering the cost of production, public awareness and best infrastructure. Solar energy is the need of the day and research on the solar cells has a promising future worldwide.

\section{References}

[1] Chu, Y. and Meisen, P. (2011) Review and Comparison of Different Solar Energy Technologies. Report of Global 
Energy Network Institute (GENI), Diego.

[2] Choubey, P.C., Oudhia, A. and Dewangan, R. (2012) A Review: Solar Cell Current Scenario and Future Trends. Recent Research in Science and Technology, 4, 99-101.

[3] McEvoy, A., Castaner, L. and Markvart, T. (2012) Solar Cells: Materials, Manufacture and Operation. 2nd Edition, Elsevier Ltd., Oxford, 3-25.

[4] Fahrenbruch, A.L. and Bube, R.H. (1983) Fundamentals of Solar Cells. Academic Press Inc., New York.

[5] (2015-2016) Energy from the Sun, Student Guide. National Energy Education Development Project (NEED).

[6] Grisham, L.R. (2008) Nuclear Fusion in: Future Energy, Improved, Sustainable and Clean Options for our Planet, Edited by Trevor M. Letcher, 2nd Edition, Elsevier Ltd., Amsterdam, 291-301.

[7] Rana, S. (2013) A Study on Automatic Dual Axis Solar Tracker System using 555 Timer. International Journal of Scientific \& Technology Research, 1, 77-85.

[8] Bertolli, M. (2008) Solar Cell Materials. Course: Solid State II. Department of Physics, University of Tennessee, Knoxville.

[9] Wall, A. (2014) Advantages and Disadvantages of Solar Energy. Process Industry Forum, 7 August 2013. Web. 2 February 2014.

[10] Bagher, A.M., Vahid, M.M.A. and Mohsen, M. (2015) Types of Solar Cells and Application. American Journal of Optics and Photonics, 3, 94-113.

[11] Whitburn, G. (2012) Exploring Green Technology, Fundamental Advantages and Disadvantages of Solar Energy.

[12] Peplow, M. (2014) Organic Synthesis: The Robo-Chemist. Nature, 512, 20-22. http://dx.doi.org/10.1038/512020a

[13] Tsoutsos, T., Frantzeskaki, N. and Gekas, V. (2005) Environmental Impacts from the Solar Energy Technologies. Energy Policy, 33, 289-296. http://dx.doi.org/10.1016/S0301-4215(03)00241-6

[14] Yadav, A. and Kumar, P. (2015) Enhancement in Efficiency of PV Cell through P\&O Algorithm. International Journal for Technological Research in Engineering, 2, 2642-2644.

[15] Castellano, R. (2010) Solar Panel Processing. Old City Publishing Inc., Philadelphia.

[16] Srinivas, B., Balaji, S., Nagendra Babu, M. and Reddy, Y.S. (2015) Review on Present and Advance Materials for Solar Cells. International Journal of Engineering Research-Online, 3, 178-182.

[17] Wurfel, P. and Wurfel, U. (2009) Physics of Solar Cells: From Basic Principles to Advanced Concepts. John Wiley \& Sons, Hoboken.

[18] Dmitrijev, S. (2006) Principles of Semiconductor Devices. Oxford University Press, Oxford.

[19] Saga, T. (2010) Advances in Crystalline Silicon Solar Cell Technology for Industrial Mass Production. NPG Asia Materials, 2, 96-102. http://dx.doi.org/10.1038/asiamat.2010.82

[20] Jayakumar, P. (2009) Solar Energy Resource Assessment Handbook. Renewable Energy Corporation Network for the Asia Pacific.

[21] Chopra, K.L., Paulson, P.D. and Dutt, V. (2004) Thin-Film Solar Cells: An Overview. Progress in Photovoltaics, 12, 69-92. http://dx.doi.org/10.1002/pip.541

[22] Imamzai, M., Aghaei, M., Hanum Md Thayoob, Y. and Forouzanfar, M. (2012) A Review on Comparison between Traditional Silicon Solar Cells and Thin-Film CdTe Solar Cells. Proceedings of National Graduate Conference (NatGrad 2012), Tenaga Nasional Universiti, Putrajaya Campus, 8-10 November 2012, 1-5.

[23] Types of Solar Panels, Grein Energy. Published 22 April 2015.

[24] Maehlum, M.A. (2015) Energy Informative The Homeowner’s Guide To Solar Panels, Best Thin Film Solar PanelsAmorphous, Cadmium Telluride or CIGS? Last updated 6 April 2015.

[25] Yogi Goswami, D. and Kreith, F. (2007) Handbook of Energy Efficiency and Renewable Energy. CRC Press, Boca Raton.

[26] Luque, A. and Hegedus, S. (2003) Handbook of Photovoltaic Science and Engineering. 2nd Edition, John Wiley \& Sons, Ltd., Hoboken. http://dx.doi.org/10.1002/0470014008

[27] Elsabawy, K.M., El-Hawary, W.F. and Refat, M.S. (2012) Advanced Synthesis of Titanium-Doped-Tellerium-Camium Mixtures for High Performance Solar Cell Applications as One of Renewable Source of Energy. International Journal of Chemical Sciences, 10, 1869-1879.

[28] Badawy, W.A. (2015) A Review on Solar Cells from Si-Single Crystals to Porous Materials and Quantum Dots. Journal of Advanced Research, 6, 123-132. http://dx.doi.org/10.1016/j.jare.2013.10.001

[29] Sethi, V.K., Pandey, M. and Shukla, P. (2011) Use of Nanotechnology in Solar PV Cell. International Journal of Chemical Engineering and Applications, 2, 77-80. 
[30] Andorka, F. (2014) CIGS Solar Cells Simplified. Solar Power World. http://www.solarpowerworldonline.com/2014/01/cigs-solar-cells-simplified/

[31] Razykov, T.M., Ferekides, C.S., Morel, D., Stefanakos, E., Ullal, H.S. and Upadhyaya, H.M. (2011) Solar Photovoltaic Electricity: Current Status and Future Prospects. Solar Energy, 85, 1580-1608. http://dx.doi.org/10.1016/j.solener.2010.12.002

[32] Hoppe, H. and Sariciftci, N.S. (2008) Polymer Solar Cells. Advances in Polymer Science, 214, 1.

[33] Dubey, S., Sarvaiya, J.N. and Seshadri, B. (2013) Temperature Dependent Photovoltaic (PV) Efficiency and Its Effect on PV Production in the World: A Review. Energy Procedia, 33, 311-321. http://dx.doi.org/10.1016/j.egypro.2013.05.072

[34] Ganesh, B.N.V.S. and Supriya, Y.V. (2013) Recent Advancements and Techniques in Manufacture of Solar Cells: Organic Solar Cells. International Journal of Electronics and Computer Science Engineering, 2, 565-573.

[35] Jassen, R. Introduction to Polymer Solar Cells. http://www.eet.bme.hu/ plesz/Gyarmati\%20Adam/2.pdf

[36] Leroy, F. (2003) A Century of Nobel Prize Recipients: Chemistry, Physics, and Medicine. CRC Press, Hoboken. http://dx.doi.org/10.1201/9780203014189

[37] Alex, C., Mayer, Shawn, R., Scully, Brian, E., Hardin, Michael, W., Rowell and Michael, D. McGehee (2007) Polymer-Based Solar Cells: A Review. Materials Today, 10, 28-33. http://dx.doi.org/10.1016/S1369-7021(07)70276-6

[38] Wudl, F. and Srdanov, G. (1993) Conducting Polymer Formed of Poly (2-Methoxy-5-(2'-Ethylhexyloxy)-P-Phenylene Vinylene). US Patent 5,189,136.

[39] Li, G., Zhu, R. and Yang, Y. (2012) Polymer Solar Cells. Nature Photonics, 6, 153-161. http://dx.doi.org/10.1038/nphoton.2012.11

[40] Brabec, C.J., Shaheen, S.E., Winder, C. and Sariciftci, N.S. (2002) Effect of LiF/Metal Electrodes on the Performance of Plastic Solar Cells. Applied Physics Letters, 80, 1288. http://dx.doi.org/10.1063/1.1446988

[41] Zhu, R., Kumar, A. and Yang, Y. (2011) Polarizing Organic Photovoltaics. Advanced Materials, 23, 4193-4198. http://dx.doi.org/10.1002/adma.201101514

[42] Li, B., Wang, L., Kang, B., Wang, P. and Qiu, Y. (2006) Review of Recent Progress in Solid-State Dye-Sensitized Solar Cells. Solar Energy Materials and Solar Cells, 90, 549-573. http://dx.doi.org/10.1016/j.solmat.2005.04.039

[43] Zhan, J., Sun, P., Jiang, S., Sun, X. and Lund, T. (2006) An Investigation of the Performance of Dye-Sensitized Nanocrytsalline Solar Cell with Anthocyanin Dye and Ruthenium Dye as the Sensitizers. Roskilde University, Roskilde.

[44] Graetzel, M., Janssen, R.A.J., Mitzi, D.B. and Sargent, E.H. (2012) Materials Interface Engineering for SolutionProcessed Photovoltaics. Nature, 488, 304-312. http://dx.doi.org/10.1038/nature11476

[45] Nozik, A.J. (2010) Nanoscience and Nanostructures for Photovoltaics and Solar Fuels. NANO Letters, 10, $2735-2741$. http://dx.doi.org/10.1021/nl102122x

[46] Suhaimi, S., Shahimin, M.M., Alahmed, Z.A., Chyský, J. and Reshak, A.H. (2015) Materials for Enhanced Dye-Sensitized Solar Cell Performance: Electrochemical Application. International Journal of Electrochemical Science, 10, 2859.

[47] Liang, M., Xu, W., Cai, F.S., Chen, P.Q., Peng, B., Chen, J. and Li, Z.M. (2007) New Triphenylamine-Based Organic Dyes for Efficient Dye-Sensitized Solar Cells. The Journal of Physical Chemistry C, 111, 4465-4472. http://dx.doi.org/10.1021/jp067930a

[48] Barnes, P.R.F., Anderson, A.Y., Koops, S.E., Durrant, J.R. and O’Regan, B.C. (2009) Electron Injection Efficiency and Diffusion Length in Dyesensitized Solar Cells Derived from Incident Photon Conversion Efficiency Measurements. The Journal of Physical Chemistry C, 113, 1126-1136. http://dx.doi.org/10.1021/jp809046j

[49] Philipps, S.P., Bett, A.W., Horowitz, K. and Kurtz, S. (2015) Current Status of Concentrator Photovoltaics (CPV) Technology. Report Version 1.2, Fraunhofer Institute for Solar Energy Systems (NREL), September 2015.

[50] Mohanta, P. R., Patel, J., Bhuva, J. and Gandhi, M. (2015) A Review on Solar Photovoltaics and Roof Top Application of It. International Journal of Advanced Research in Science, Engineering and Technology, 2, 2394-2444.

[51] Ahn, N., Son, D.-Y., Jang, I.-H., Kang, S.M., Choi, M. and Park, N.-G. (2015) Highly Reproducible Perovskite Solar Cells with Average Efficiency of $18.3 \%$ and Best Efficiency of $19.7 \%$ Fabricated via Lewis Base Adduct of Lead(II) Iodide. Journal of the American Chemical Society, 137, 8696-8699. http://dx.doi.org/10.1021/jacs.5b04930

[52] Tina Casey (2015) An Article on Perovskites Will Power New Low-Cost \& Highly Efficient Solar Cells. Clean Technical, 3 July 2015.

[53] Shi, D., Zeng, Y. and Shen, W. (2015) Pervoskite/c-Si Tandem Solar Cell with Inverted Nanopyramids: Realizing High Efficiency by Controllable Light Trapping. Scientific Reports, 5, Article No. 16504. 
http://dx.doi.org/10.1038/srep16504

[54] http://www.altenergy.org/renewables/solar/latest-solar-technology.html

[55] Wu, Y. and Gorder, P.F. (2014) Nature Communications. Published on 3 October 2014.

[56] Nabhani, N. and Emami, M. (2013) Nanotechnologies and Its Applications in Solar Cells. International Conference on Mechanical and Industrial Engineering (ICMIE'2013), Penang, 28-29 August 2013, 88-91. 